\title{
Article/Artigo
}

\section{Descriptive study of HTLV infection in a population of pregnant women from the State of Pará, Northern Brazil}

\author{
Estudo descritivo da infecção pelo HTLV em uma população de gestantes do Estado do Pará, \\ norte do Brasil
}

\author{
Carina Guilhon Sequeira ${ }^{1,2}$, Bruna Pedroso Tamegão-Lopes ${ }^{3}$, Eduardo José Melo dos Santos ${ }^{4}$, Ana Maria \\ Revoredo Ventura ${ }^{1,2}$, Maria Isabel Moraes-Pinto ${ }^{4}$ and Regina Célia de Menezes Succi ${ }^{4}$
}

\begin{abstract}
Introduction: In Brazil, studies have shown that HTLV seroprevalence among pregnant women varies from 0 to $1.8 \%$. However, this seroprevalence was unknown in the State of Pará, Brazil. The present study describes, for the first time, the HTLV seroprevalence among pregnant women from the State of Pará, Northern Brazil. Methods: 13,382 pregnant women were submitted to HTLV screening during prenatal care, and those with non-seronegative results to anti-HTLV were submitted to Western blot (WB) test to confirm and separate HTLV-1 and HTLV-2 carriers. Results: HTLV seroprevalence in the population of pregnant women was $0.3 \%$, and HTLV- 1 was identified in $95.3 \%$ of patients. The demographic profile of HTLV carriers was as follows: women with age between 20 and 40 years old (78.4\%); residing in the metropolitan region of Belém, Pará (67.6\%); and with educational level of high school $(56.8 \%)$. Other variables related to infection were as follows: beginning of sexual intercourse between the age of 12 and 18 years old $(64.9 \%)$ and have being breastfed for more than 6 months (51.4\%). Most of the women studied had at least two previous pregnancies $(35.1 \%)$ and no abortion (70.3\%). Coinfections (syphilis and HIV) were found in $10.8 \%(4 / 37)$ of these pregnant women. Conclusions: Seroprevalence of HTLV infection in pregnant women assisted in basic health units from the State of Pará, Northern Brazil, was $0.3 \%$ similar to those described in other Brazilian studies. The variables related to infection were important indicators in identifying pregnant women with a higher tendency to HTLV seropositivity, being a strategy for disease control and prevention, avoiding vertical transmission.
\end{abstract}

Keywords: HTLV. Pregnant women. Seroprevalence.

\section{RESUMO}

Introdução: No Brasil, estudos mostram que a soroprevalência do HTLV entre gestantes varia de 0 a 1,8\%. Contudo, esta soroprevalência era desconhecida no Estado do Pará, Brasil. O presente estudo descreve, pela primeira vez, a soroprevalência do HTLV entre gestantes do Estado do Pará, Norte do Brasil. Métodos: 13,382 gestantes foram submetidas à triagem para HTLV durante o pré-natal, e aquelas com sorologia alterada para anti-HTLV foram submetidas ao teste de Western Blot (WB), para confirmar e discriminar portadoras do HTLV-1 e do HTLV2. Resultados: A soroprevalência do HTLV na população de gestantes foi de $0,3 \%$, sendo o HTLV-1 identificado em $95,3 \%$ das pacientes. O perfil demográfico das portadoras do HTLV foi de: mulheres com idade entre $20-40$ anos (78,4\%); residentes na região metropolitana de Belém (67,6\%) e com nível educacional igual ao ensino médio (56,8\%). Outras variáveis relacionadas à infecção foram: início das relações sexuais compreendido entre 12-18 anos $(64,9 \%)$, e ter sido aleitada mais de 6 meses $(51,4 \%)$. A maior parte das mulheres estudadas teve ao menos duas gestações anteriores $(35,1 \%)$; e nenhum aborto $(70,3 \%)$. Co-infecções (sífilis e HIV) foram descritas em 10,8\% (4/37) das gestantes. A soroprevalência da infecção pelo HTLV em gestantes atendidas em Unidades Básicas de Saúde do Estado do Pará, Norte do Brasil foi de $0,3 \%$ semelhante à descrita em outros estudos brasileiros. As variáveis relacionadas com a infecção são indicadores importantes na identificação de gestantes com maior tendência a soropositividade pelo HTLV, sendo uma estratégia de controle e prevenção, evitando a transmissão vertical.

Palavras-chaves: HTLV. Gestantes. Soroprevalência.

1. Setor de Parasitologia, Instituto Evandro Chagas, Belém, PA. 2. Departamento de Saúde Integrada, Universidade Estadual do Pará, Belém, PA. 3. Instituto de Ciências Biológicas, Universidade Federal do Pará, Belém, PA. 4. Departamento de Pediatria, Universidade Federal de São Paulo, São Paulo, SP. Address to: Dra. Carina Guilhon Sequeira. CCBS/Universidade do Estado do Pará. Travessa Perebebuí 2623, Marco, 66050-662 Belém, PA, Brasil.

Phone: 5591 3276-2023.

e-mail: carina.gs@ig.com.br

Received in $16 / 08 / 2011$

Accepted in 11/10/2011

\section{INTRODUCTION}

Human T-lymphotropic virus types 1 and 2 (HTLV-1 and HTLV-2) are human retroviruses with tropism for T-lymphocytes ${ }^{1}$. These HTLV types were described in the $1980 \mathrm{~s}^{2}$, and in 2005 , two other types have been described, HTLV-3 and HTLV-4, which are currently being investigated for molecular characterization and for a possible association with human disease $\mathrm{e}^{3,4}$. The exact number of HTLV-1-seropositive individuals in the world is not known; it is estimated that approximately 15-20 million people live with HTLV infection worldwide . $^{5}$ The seroprevalence rates differ according to the geographic area, socio-demographic composition of the population studied, and individual risk behaviors ${ }^{6}$ associated with the dissemination of blood (injected drug use and blood transfusion) and other biological fluids exchanged during sexual relations (maleto-female and female-to-male), as well as vertical (mother-to-child) transmission ${ }^{7}$. Mother-to-child transmission occurs in $20 \%$ of offspring from an infected mother, and it has been related to the mother's proviral load, high antibody titers, and prolonged breastfeeding ${ }^{8,9}$. Postnatal infection by breastfeeding via human milk seems to play the most important role in vertical transmission ${ }^{10}$, and it may occur by means of breastfeeding by wet nurses or cross-breastfeeding (horizontal transmission) ${ }^{11}$. Few studies about vertical transmission were done, as well as the follow-up of exposed children during pregnancy, birth, and breastfeeding ${ }^{12-14}$.

Seroprevalence of HTLV infection was well described in the blood donors' population and less documented in pregnant women population ${ }^{7,15,16}$. Brazilian studies reporting the seroprevalence of HTLV infection in pregnant women population described rates ranging from 0 to $1.8 \%^{17-22}$. In the State of Pará, seroprevalence of HTLV infection in pregnant women was unknown. Interventions to prevent vertical transmission and HTLV-related diseases include prenatal/neonatal screening in 
geographic areas with high prevalence, and encouraging seropositive mothers to provide a milk formula rather than breast milk for their infants ${ }^{23,24}$, as approximately $1-5 \%$ of children infected through vertical transmission will develop ATL (adult T-cell leukemia) ${ }^{6}$. The aim of the present study was to describe HTLV seroprevalence and associated risk factors in pregnant women assisted in basic health units from Pará, Northern Brazil and to verify the presence of coinfection with Treponema pallidum (syphilis) and HIV.

\section{METHODS}

\section{Study design and patients' selection criteria}

The study was conducted from February to November of 2008 through the program denominated Mother to Child, from the State Secretary of Public Health, whose main objective was to implement improvements in prenatal assistance in the region. During the mentioned period, 19 distinct municipalities joined the program, and 13,382 pregnant women were interviewed during the prenatal care consultations performed in health care units. Serological tests for infectious agents, such as syphilis, HIV-1 and HIV-2, HTLV-1 and HTLV-2, cytomegalovirus, hepatitis $\mathrm{B}$, hepatitis $\mathrm{C}$, toxoplasmosis, and rubella, were made. Serological screening was performed by finger prick, and blood samples were collected through the dried blood spot (DBS) method.

Only pregnant women with an anti-HTLV reagent test (Murex HTLV-I+II, Dartford, England) were included in this study. The samples, which tested reactive in the screening test, were confirmed through Western blot (WB) test (HTLV-I/II, Gene Labs Diagnostics").

Variables, such as age, local of residence, sexual behavior (number of sexual partners, age of first sexual intercourse), intravenous drug use, obstetric history (number of pregnancies, number of abortions), history of receiving blood transfusion, breastfeeding, syphilis, and HIV coinfections, were used to describe the epidemiological profile associated with HTLV infection. This information was obtained from a data bank from APAE/IDIPE (Association of Parents and Friends of Exceptional/Institute of Diagnostic, Research and Teaching).

\section{Ethical considerations}

The present study was approved by the ethics committee of Pará State University (UEPA).

\section{RESULTS}

From the 13,382 pregnant women initially involved in this study, $43(0.3 \%)$ had an anti-HTLV reagent test result in the serological screening. This population represented the $10.7 \%$ of pregnant women who attended the public prenatal programs in the State of Pará, Brazil, in 2008.

WB test was used to confirm HTLV-1 and HTLV-2 infection: 41 (95.3\%) women were considered as HTLV positive (positive WB test); 39 (95.1\%) pregnant women were positive to HTLV-1 and one $(2.4 \%)$ to HTLV-2, and one had an indeterminate result in WB (2.4\%). Among those 41 HTLV-carriers, 37 (90.2\%) women had the epidemiological profile available related with HTLV infection. All those women were asymptomatic.

Demographic data revealed that the HTLV pregnant women detected in this study have ages ranging from 20 to 40 years old (mean age: $27.8 \pm 7.6$ years old; $78.4 \%$ ); educational level of high school (56.8\%); and residing in the metropolitan region of Belém, the capital of the State of Pará (67.6\%) (Table 1). Other variables more frequently detected with HTLV infection were the beginning of sexual intercourse between the age of 12 and 18 years old (64.9\%) and being breastfed for more than 6 months (51.4\%) (Table 2). Other variables, such as the use of intravenous drugs (2.7\%), number of sexual partners (less than 3 partners; 29.7\%), blood transfusion (8.1\%), and coinfection (11\%), were irrelevant to HTLV infection in this population of pregnant women. The distribution of pregnancies and abortions revealed that most part of the studied women had at least two previous pregnancies (35.1\%) and no abortion (70.3\%). Coinfection analysis revealed that from the 37 HTLV carriers with epidemiological data, three had a syphilis reagent test (8.1\%), and one had an HIV reagent test (2.7\%).

TABLE 1 - Demographic data among pregnant HTLV-carriers in the State of Pará, Brazil.

\begin{tabular}{lrc}
\hline Variable & Number & Percentage \\
\hline Age (years) & 6 & 16.2 \\
$15-19$ & 29 & 78.4 \\
$20-39$ & 2 & 5.4 \\
$40-49$ & & \\
\hline Local of residence & 2 & 5.4 \\
Baixo Amazonas & 4 & 10.8 \\
Marajó & 25 & 67.6 \\
Belém metropolitan region & 2 & 5.4 \\
northeastern Pará & 2 & 5.4 \\
southeastern Pará & 2 & 5.4 \\
not informed & & \\
Educational level & 5 & 13.5 \\
elementary school & 21 & 56.8 \\
high school & 1 & 2.7 \\
higher education & 10 & 27.0 \\
not informed & &
\end{tabular}

TABLE 2 - Sexual initiation and breastfeeding distribution among pregnant HTLV-carriers in the State of Pará, Brazil.

\begin{tabular}{lcc}
\hline Variable & Number & Percentage \\
\hline Sexual initiation: age of first sexual intercourse (years) & & \\
$\quad<12$ & 1 & 2.7 \\
$12-18$ & 24 & 64.9 \\
$>18$ & 6 & 16.2 \\
$\quad$ not informed & 6 & 16.2 \\
\hline Breastfeeding (months) & & \\
$\quad \leq 6$ & 5 & 13.5 \\
$>6$ & 19 & 51.4 \\
not informed & 4 & 10.8 \\
\hline
\end{tabular}

HTLV: human T-lymphotropic virus.

\section{DISCUSSION}

This is the first prevalence study of HTLV infection in the population of pregnant women from public prenatal programs in the State of Pará, Brazil. Our results indicated a seroprevalence of $0.3 \%$ of HTLV infection. This seroprevalence was lower than those reported by Bittencourt and colleagues ${ }^{25}$ and Lima and Viana ${ }^{26}$, but higher than those reported by other authors ${ }^{18,22,27-31}$. 
The mean age observed among HTLV-positive pregnant women was similar to those described by other authors ${ }^{25,30}$. Onset of sexual activity between the age of 12 and 18 years old was a variable reported by a significant number of pregnant women $(64.9 \%)$ with HTLV infection in this study. It was well-defined that male-to-female HTLV transmission occurs more frequently than female-to-male transmission ${ }^{32,33}$. When this biological factor is associated with a long time of sexual life, and/or multiple numbers of sexual partners, and/or non-use of condoms during sexual intercourse, the HTLV infection through sexual transmission seems to be more efficient.

Another variable related to HTLV infection was breastfeeding for more than 6 months. Studies have reported HTLV infection in mother's milk-fed infants several years after birth ${ }^{34}$, depending on the duration of feeding ${ }^{35,36}$. It is usually considered as a risk factor for HTLV infection with an exposure period higher than 6 months, which denominates the long-term breast-feeder. It represents a greater risk for acquiring HTLV infection, showing the necessity of the serological screening for HTLV infection among pregnant women during prenatal follow-up ${ }^{18}$.

Although the study design does not permit to clarify which was real via HTLV transmission in this population and the researchers were not able to exclude other routes of contamination, it has been shown that some variables were more related to HTLV infection in this population of pregnant women from Northern Brazil.

The HTLV-carrier women involved in this study were orientated about the possibility of HTLV vertical transmission. They were advised to avoid breastfeeding, and all of them received milk formula to feed their children. It is important to note that no one of these women knew about their infectious status. In parallel, the children who were born to these women were followed-up to investigate a possible vertical transmission.

Moreover, it is necessary to emphasize that this population represented only $10.7 \%$ of the pregnant women who attended the public prenatal care programs in the State of Pará, Brazil, in 2008. Therefore, it is expected that the absolute number of HTLV pregnant carriers is higher, thus, reinforcing the importance of identifying pregnant women with HTLV infection as a strategy to develop public health politics to control the disease and prevent its vertical transmission.

\section{ACKNOWLEDGMENTS}

To researchers, collaborators, and patients who had collaborated to the present study.

\section{CONFLICT OF INTEREST}

The authors declare that there is no conflict of interest.

\section{FINANCIAL SUPPORT}

This work was supported by The Secretary of Public Health of Pará State; Associação de Pais e Amigos dos Excepcionais (APAE) Belém, Pará, $n^{\circ}$ 01/2008; State University of Pará (03461/07); Evandro Chagas Institute (IEC), Pará, Brazil, and FAPESPA (Brazilian funding; $\mathrm{n}^{\circ}$ 030/2007). C.G.S is supported by CAPES (Brazilian Funding Agency; $n^{\circ} 4529 / 05$; Post-graduation in Science Medical)/B.P.T.L is supported by CAPES (Brazilian Funding Agency; Post-graduation in Biology of Infectious and Parasitological Agents; PhD fellowship).

\section{REFERENCES}

1. Richardson J, Reyburn HT, Luque, Valez-Gomez M, Strominger JL. Definition of polymorphic residues on killer Ig-like receptor proteins which contribute to the HLA-C binding sites. Europ J Immun 2000; 30:1480-1485.

2. Gallo RC. The Discovery of the first human retrovirus: HTLV-1 and HTLV-2. Retrovirol 2005; 2:17.

3. Callatini S, Chevalier SA, Duprez R, Bassot S, Froment A, Mahieux R, et al Discovery of a new human T-cell lymphotropic virus (HTLV-3) in Central Africa. Retrovirol 2005; 2:30.

4. Wolfe ND, Heneine W, Carr JK, Gracia AD, Shanmugam V, Tamoufe U, et al Emergence of unique primate T-lymphotropic viruses among central African bushmeat hunters. PNAS 2005; 102:7994-7999.

5. De The G, Kazanji M. An HTLV-I/II vaccine: from animal models to clinical trials? J Acq Immun Def Synd Hum Retrovirol 1996; 13 (suppl 1):191-198.

6. Proietti FA, Carneiro-Proietti ABF, Catalan-Soares BC, Murphy EL. Global epidemiology of HTLV-I infection and associated diseases. Oncogene 2005; 24:6058-6068.

7. Ishak R, Vallinoto AC, Azevedo VN, Ishak MOG. Epidemiological aspects of retrovirus (HTLV) infection among Indian populations in the Amazon Region of Brazil. Cad Saude Publica 2003; 19:109-118.

8. Kinoshita K, Amagashi T, Hino S, Doi H, Yamanouchi K, Ban N, et al. Milk-borne transmision of HTLV-I from carrier mothers to their children. Jap J Cancer Res $1987 ; 78: 674-680$

9. Ureta-Vidal A, Angelin-Duclos C, Tortevoye P, Murphy E, Lepere JF, Buigues RP, et al. Mother-to-child transmission of human T-cell-leukemia/lymphoma virus type I: implication of high antiviral antibody titer and high proviral load in carrier mothers. Int J Cancer 1999; 82:832-836.

10. Cann AJ, Chen SY. Human T-cell leukemia virus type I and II. In: Fields BN Knipe DM, Howley PM, editors. Fields Virology. $3^{\text {rd }}$ Ed. Philadelphia: Lippincott-Raven Publishers; 1996. p. 1849-1880.

11. Bittencourt AL, Primo J, Oliveira MFP. Manifestations of the human T-cell lymphotropic virus type I infection in childhood and adolescence. J Pediat 2006; 82:411-420

12. Witkor SZ, Pate EJ, Rosenburg PS, Barnett M, Palmer P, Medeiros D, et al. Motherto-child transmission of human T-cell lymphotropic virus type I associated with prolonged breast-feeding. J Hum Virol 1997; 1:37-44.

13. Hino S, Sugiyama H, Doi H, Ishimaru T, Yamabe T, Tsuji Y, et al. Breaking the cycle of HTLV-I transmission via carrier mothers' milk. Lancet 1997; 8551:158-159.

14. Maloney EM, Wiktor SZ, Palmer P, Cranston B, Pate EJ, Cohn S, et al. A cohort study of health effects of human T-cell lymphotropic virus type I infection in Jamaican children. Pediat 2003; 112:e136-142.

15. Carneiro-Proietti ABF, Catalan-Soares B, Proietti FA, GIPH (Interdisciplinary HTLV-I/II Research Group). Human T Cell Lymphotropic Viruses (HTLV-I/ II) in South America: Should It Be a Public Health Concern? J Biomed Sci 2002 9:587-595.

16. Hlela C, Shepperd S, Khumalo MP, Taylor GP. The Prevalence of Human T-cell Lymphotropic Virus Type 1 in the General Population is Unknown. AIDS Rev 2009; 11:205-214

17. Machado Filho AC, SardinhaJFJ, Ponte RL, Costa EP, Silva SS, Martinez-Espinosa FA. Prevalence of infection for HIV, HTLV, HBV and of syphilis and Chlamydia in pregnant women in a tertiary health unit in the western Brazilian Amazon Region. Rev Bras Ginecol Obstet 2010; 32:176-183.

18. Olbrich-Neto J, Meira DA. Soroprevalência de vírus linfotrópico de células T humanas, vírus da imunodeficiência humana, sífilis e toxoplasmose em gestantes de Botucatu - São Paulo - Brasil. Fatores de risco para vírus linfotrópico de células T humanas. Rev Soc Bras Med Trop 2004; 37:28-32.

19. Lima LHM, Viana MC. Prevalence and risk factors for HIV, syphilis, hepatitis B hepatitis C, and HTLV-I/II infection in low-income postpartum and pregnant women in Greater Metropolitan Vitória, Espírito Santo State, Brazil. Cad Saude Publica 2009; 25:668-676.

20. Carles G, Tortevoye P, Tuppin P, Ureta-Vidal A, Peneau C, El Guindi W, Gessain A Infection par le rétrovirus HTLV-1 et grossesse. J Gynecol Obstet Biol Reprod $2004 ; 33: 14-20$. 
21. Figueiró-Filho EA, Lopes AHA, Senefonte FRA, Souza Junior VG, Botelho CA, Duarte G. T-cell leukemia virus infection in pregnant women in a Central-Western state of Brazil. Rev Bras Ginecol Obstet 2005; 27:719-725

22. Ribeiro MA, Proietti FA, Martins ML, Januário JN, Ladeira RVP, Oliveira MF, et al. Geographic distribution of human T-lymphotropic virus types 1 and 2 among mothers of newborns tested during neonatal screening, Minas Gerais, Brazil. Rev Panam Salud Publica 2010; 27:330-337.

23. Blattner WA. Epidemiology of HTLV-1 and associated diseases. In: Blattner WA, editor. Hum Retrovirol HTLV. New York: Raven; 1990. p. 251-265.

24. Hino S, Katamine S, Kawase K, Miyamoto T, Doi H, Tsuji Y, et al. Intervention of maternal transmission of HTLV-1 in Nagasaki, Japan. Leukemia 1994; 8 (suppl 1):68-70.

25. Bittencourt AL, Dourado E, B Filho P, Santos M, Valadão E, Alcântara LC, et al. Human T-cell lymphotropic vírus type 1 among pregnant women in northeastern Brazil. J Acq Imm Defic Synd 2001; 26:490-494.

26. Lima LHM, Viana MC. Prevalence and risk factors for HIV, syphilis, hepatitis B, hepatitis C, and HTLV-I/II infection in low-income postpartum and pregnant women in Greater Metropolitan Vitória, Espírito Santo State, Brazil. Cad Saude Publica 2009; 25:668-676.

27. Oliveira SR, Avelino MM. Soroprevalência do vírus linfotrópico humano tipo I entre gestante em Goiânia, GO, Brasil. Rev Brasil Ginecol Obstet 2006; 28:467-482.

28. Figueiró-Filho EA, Lopes AHA, Senefonte RA, Souza Junior VG, Botelho CA, Duarte G. Infecção pelo vírus linfotrópico de células T humanas e transmissão vertical em gestantes do estado da Região Centro-Oeste do Brasil. Rev Brasil Ginecol Obstet 2005; 27:719-725.
29. Ydy RRA, Ferreira D, Souto FJD, Fontes CJF. Prevalência da infecção pelo vírus linfotrópico humano de células T - HTLV-1/2 entre puérperas de Cuiabá, Estado de Mato Grosso, 2006. Rev Soc Bras Med Trop 2009; 42:28-32.

30. Dal Fabbro MMFJ, Cunha RV, Bóia MN, Portela P, Botelho CA, Freitas GM, et al. Infecção pelo HTLV 1/2: atuação no pré-natal como estratégia de controle da doença no Estado de Mato Grosso do Sul. Rev Soc Brasil Med Trop 2008; 41:148-151.

31. Machado-Filho AC, Sardinha JFJ, Ponte RL, Costa EP, Silva SS, Martinez-Espinosa F. Prevalência de infecção por HIV, HTLV, VHB e de sífilis e clamídia em gestantes numa unidade de saúde terciária na Amazônia ocidental brasileira. Rev Brasil Ginecol Obstet 2010; 32:176-183.

32. Catalan-Soares B, Carneiro-Proietti AB, Proietti FA, Grupo Interdisciplinar de Pesquisas em HTLV. Vírus-T linfotrópico humano em familiares de candidatos a doação de sangue soropositivos: disseminação silenciosa. Rev Panam Salud Publica/Pan American J Pub Health 2004; 16:387-394.

33. Moriuchi M and Moriuchi H. Seminal Fluid Enhances Replication of Human T-Cell Leukemia Virus Type 1: Implications for Sexual Transmission. J Virol 2004; 78:12709-12711.

34. Ando Y, Matsumoto Y, Nakano S, Saito K, Kakimoto K, Tanigawa T, et al. Longterm Follow up Study of Vertical HTLV-I Infection in Children Breast-fed by Seropositive Mothers. J Infec 2003; 46: 177-179.

35. Ando Y, Ekuni Y, Matsumoto Y, Nakano S, Saito K, Kakimoto K, et al. Long-term serological outcome of infants who received frozen-thawed milk from human T-lymphotropic virus type-I positive mothers.J Obstet Gynecol Res 2004; 30:436-438.

36. Takezaki T, Tajima K, Ito M, Ito S, Tachibana K, Matsushita Y. Short-term breastfeeding may reduce the risk of vertical transmission of HTLV-I. The Tsushima ATL Study Group. Leukemia 1997; 11(suppl 3):60-62. 